\title{
Studies on the Production of Milk-clotting Enzymes, Proteolytic Enzymes and Mucilage by Fungi
}

\author{
By A. F. ABDEL-FATTAH AND NADIA M. EL-HAWWARY \\ Laboratory of Microbial Chemistry, National Research Centre, Dokki, Cairo, Egypt
}

AND A. S. AMR

Department of Plasma and Blood Products, Ministry of Public Health, Agouza, Cairo, Egypt

(Received 12 November 1973; revised 30 April 1974)

SUMMARY

Of 48 fungal isolates, 28 (including one Penicillium and three Aspergilli) secreted milk-clotting enzymes. This activity was in general related to the mycelial growth of a given isolate, but not with $\mathrm{pH}$ change of the culture filtrate during incubation. It was not found when mucilage was formed by isolates capable of doing so. The ratio of general proteolytic activity to milk-clotting activity varied from one organism to another, and with the age of culture of the same fungal strain.

\section{INTRODUCTION}

Attention has recently been focused on milk-clotting enzymes from micro-organisms for use as rennin substitutes (Veringa, 1961 ; Davis, 1970) and various fungi have been investigated for this purpose (Veselov, Tipograph \& Petina, 1965; Arima, Iwasaki \& Tamura, 1967; Paleva, 1969; Abdel-Fattah, Mabrouk \& El-Hawwary, 1972 $a, b$ ). The association of general proteolytic activity with most milk-clotting enzymes, however, has led to a search for micro-organisms producing the latter with low general proteolytic action (Arima et al. 1967; Abdel-Fattah et al. 1972a). In the present work, various fungi were screened for the production of these activities. A hitherto unreported phenomenon relating the production by some fungi of milk-clotting enzymes and mucilage was also examined.

\section{METHODS}

Organisms. The fungal strains used in the present work were obtained from the United States Department of Agriculture, Agricultural Research Service, Northern Utilization Research and Development Division, Peoria, Illinois 6I604, U.S.A. (NRRL) and from the fungal collection of the Centre of Cultures of the National Research Centre, Cairo, Egypt. Pseudoarachniotus roseus (Arachniotus dankallensis), a local isolate, was kindly provided by Professor H. M. Youssef, Botany Department, Faculty of Science, Alexandria University, Egypt.

Culture. Unless otherwise specified, the medium used was corn-steep solids ( $2 \%, w / v)$ plus lactose $(2 \%, w / v)$. Transfers were made from the subcultures to Dox's agar plates, which were then incubated at $30^{\circ} \mathrm{C}$ for 7 days. Liquid cultures were grown in $250 \mathrm{ml}$ flat-bottomed flasks, each containing $50 \mathrm{ml}$ sterile medium. Four discs, each of $5 \mathrm{~mm}$ diam, were cut from the 7-day-old culture plates and used for inoculating each flask. After incubation for different 
Table I. Milk-clotting activity of fungal cultures

Type of culture: surface, 7 day incubation.

\section{Micro-organism}

Aspergillus fischeri

A. flavus

A. giganteus

A. hennenbergii NRRLI736

A. niger $46 \mathrm{H}$

A. niger NRRL 372

A. niger NRRL 393

A. niger NRRL604

A. niger NRRL6I I

A. niger NRRL6I 5

A. versicolor

Cladosporium sp. 56

Cunninghamella echinulata

Epicoccum purpurascens

Mucor hiemalis

Penicillium chrysogenum

$P$. expansum

$P$. martensii

pH of culture
filtrate

$4 \cdot 2$
$3 \cdot 8$
$3 \cdot 7$
$6 \cdot 8$
$4 \cdot 7$
$6 \cdot 7$
$6 \cdot 1$
$6 \cdot 0$
$6 \cdot 2$
$5 \cdot 6$
$3 \cdot 0$
$2 \cdot 8$
$2 \cdot 8$
$6 \cdot 2$
$5 \cdot 9$
$2 \cdot 8$
$5 \cdot 3$
$2 \cdot 5$

\author{
Protein content \\ of culture filtrate \\ (mg/2.5 ml)
}

$$
\begin{array}{r}
2.13 \\
4.13 \\
5.25 \\
5.12 \\
6.63 \\
5.25 \\
5.87 \\
5.75 \\
7.50 \\
5.62 \\
3.62 \\
22.20 \\
19.00 \\
7.50 \\
4.75 \\
22.00 \\
4.12 \\
23.20
\end{array}
$$

\section{Clotting \\ time* \\ (min)}

58
50
70
270
360
63
255
20
24
17
20
5
2
240
75
$1 \cdot 5$
13
4

* Filtrates of these isolates produced clotting after overnight incubation (I2 h): Aspergillus niger NRRL 335 Curvularia lunata, Fusarium moniliforme, F. semitectum 9, Gibberella sp. I 1 , Mucor fragilis, Oospora sp. 3, Penicillium notatum 61, Rhizopus nigricans, Trichoderma viride. Filtrates of these isolates produced no clotting after I2 h: Alternaria tenuis, Aspergillus clavatus, A. funiculosus, A. niger 66, A. niger 73, Chaetomium globosum, Cladosporium sp. 54, Cunninghamella sp. 228, Fusarium equiseti, F. oxysporum, F. semitectum 4, Geotrichum candidum, Helminthosporium spiciferum (Cochliobolus spicifer), Penicillium griseofulvum NRRL2300, $\boldsymbol{P}$. lilacinum, $\boldsymbol{P}$. notatum 62, Stemphylium (Ulocladium) consortiale, Trichothecium roseum, Verticillium dahliae. Under similar conditions, $2 \mathrm{mg}$ calf rennin (Difco) in $2.5 \mathrm{ml}$ water, clotted reconstituted skim milk (10 $\mathrm{ml}$ ) in $7 \mathrm{~min}$.

periods at $30{ }^{\circ} \mathrm{C}$, the culture medium from each flask was filtered off and made up to $50 \mathrm{ml}$ with distilled water.

Protein determination. This was done by the method of Lowry, Rosebrough, Farr \& Randall (195r).

Assay of milk-clotting activity. This was done according to the method of Berridge (1952); $2.5 \mathrm{ml}$ of the enzyme sample were incubated with $10 \mathrm{ml}$ reconstituted skim milk ( $2 \mathrm{~g}$ dry skim milk/IOO $\mathrm{ml} \mathrm{o.0I} \mathrm{M}-\mathrm{CaCl}_{2}$ ) at $40^{\circ} \mathrm{C}$ and the clotting time recorded. One unit of enzyme activity was taken to be that which clotted $10 \mathrm{ml}$ milk in $10 \mathrm{~min}$.

Assay of general proteolytic activity. This was done according to the method of Bergkvist (1963) by determining the rate of hydrolysis of $\mathrm{I} \cdot 5 \%$ (w/v) casein in $0.2 \mathrm{M}$-sodium phosphate buffer ( $\mathrm{pH} 7 \cdot 4$ ) containing the enzyme, after incubation for $30 \mathrm{~min}$ at $37^{\circ} \mathrm{C}$. The increase in $E_{280}$ of tricholoroacetic acid filtrate was used as a measure of proteolytic activity; the values were calculated on the basis of $\mathrm{mg}$ enzyme protein.

\section{RESULTS AND DISCUSSION}

Of the 48 fungal isolates investigated only 28 brought about clotting of milk (Table I). On the other hand, of 16 Aspergillus strains 12 produced milk-clotting enzymes of differing activities. Aspergillus niger 604, A. niger 6I 5 and, especially, A. versicolor, were the more potent Aspergillus strains for producing active milk-clotting enzymes. 
Table 2. Milk-clotting activity, proteolytic activity and their ratio in culture filtrates of some fungal isolates

\begin{tabular}{|c|c|c|c|c|c|c|c|}
\hline Micro-organism & $\begin{array}{c}\text { Time of } \\
\text { incuba- } \\
\text { tion } \\
\text { (days) }\end{array}$ & $\begin{array}{l}\mathrm{pH} \text { of } \\
\text { culture } \\
\text { filtrates }\end{array}$ & $\begin{array}{c}\text { Protein } \\
\text { content of } \\
\text { culture } \\
\text { filtrates } \\
(\mathrm{mg} / 2.5 \mathrm{ml})\end{array}$ & $\begin{array}{l}\text { Dry wt of } \\
\text { mycelium } \\
\text { (mg/50 ml } \\
\text { medium) }\end{array}$ & $\begin{array}{c}\text { Milk- } \\
\text { clotting } \\
\text { activity, } \\
\text { MC, } \\
\text { (unit/mg } \\
\text { protein) }\end{array}$ & $\begin{array}{c}\text { Proteo- } \\
\text { lytic } \\
\text { activity, } \\
\mathrm{P}^{*}\end{array}$ & $\mathrm{MC} / \mathrm{P} \dagger$ \\
\hline Aspergillus fischeria & $\begin{array}{l}4 \\
7\end{array}$ & $\begin{array}{l}3 \cdot 3 \\
4 \cdot 2\end{array}$ & $\begin{array}{l}5.50 \\
2.13\end{array}$ & $\begin{array}{l}351 \\
625\end{array}$ & $\begin{array}{l}0.03 \\
0.08\end{array}$ & $\begin{array}{l}0.00 \\
0.00\end{array}$ & $\begin{array}{l}(\infty) \\
(\infty)\end{array}$ \\
\hline A. flavus & $\begin{array}{l}4 \\
7\end{array}$ & $\begin{array}{l}4.0 \\
3.8\end{array}$ & $\begin{array}{l}6 \cdot 00 \\
4 \cdot 13\end{array}$ & $\begin{array}{r}763 \\
1032\end{array}$ & $\begin{array}{l}0.02 \\
0.05\end{array}$ & $\begin{array}{l}0.02 \\
0.00\end{array}$ & $\begin{array}{l}I \cdot \infty \\
(\infty)\end{array}$ \\
\hline A. giganteus & $7 *$ & $3 \cdot 7$ & $5 \cdot 25$ & WG & 0.03 & 0.00 & $(\infty)$ \\
\hline A. hennenbergii NRRLI 736 & $\begin{array}{l}4 \\
7\end{array}$ & $\begin{array}{l}3 \cdot 3 \\
6.8\end{array}$ & $\begin{array}{l}4 \cdot 50 \\
5 \cdot 12\end{array}$ & $\begin{array}{l}972 \\
917\end{array}$ & $\begin{array}{l}0.04 \\
0.01\end{array}$ & $\begin{array}{l}0.00 \\
0.06\end{array}$ & $\begin{array}{l}(\infty) \\
0.12\end{array}$ \\
\hline A. niger NRRL372 & $\begin{array}{l}4 \\
7\end{array}$ & $\begin{array}{l}3 \cdot 6 \\
6 \cdot 7\end{array}$ & $\begin{array}{l}6 \cdot 00 \\
5 \cdot 25\end{array}$ & $\begin{array}{r}1033 \\
846\end{array}$ & $\begin{array}{l}0.06 \\
0.03\end{array}$ & $\begin{array}{l}0.00 \\
0.01\end{array}$ & $\begin{array}{l}(\infty) \\
2 \cdot \infty\end{array}$ \\
\hline A. niger NRRL393 & $\begin{array}{l}4 \\
7\end{array}$ & $\begin{array}{l}4 \cdot I \\
6 \cdot I\end{array}$ & $\begin{array}{l}4.50 \\
5 \cdot 87\end{array}$ & $\begin{array}{l}932 \\
854\end{array}$ & $\begin{array}{l}0.01 \\
0.01\end{array}$ & $\begin{array}{l}0.02 \\
0.00\end{array}$ & $\begin{array}{l}0.38 \\
(\infty)\end{array}$ \\
\hline A. niger NRRL604 & $\begin{array}{l}4 \\
7\end{array}$ & $\begin{array}{l}3.5 \\
6.0\end{array}$ & $\begin{array}{l}5 \cdot 37 \\
5 \cdot 75\end{array}$ & $\begin{array}{l}978 \\
780\end{array}$ & $\begin{array}{l}0.11 \\
0.09\end{array}$ & $\begin{array}{l}0.00 \\
0.00\end{array}$ & $\begin{array}{l}(\infty) \\
(\infty)\end{array}$ \\
\hline A. niger NRRL6I I & $\begin{array}{l}4 \\
7\end{array}$ & $\begin{array}{l}4 \cdot 1 \\
6 \cdot 2\end{array}$ & $\begin{array}{l}5 \cdot 37 \\
7 \cdot 50\end{array}$ & $\begin{array}{l}926 \\
822\end{array}$ & $\begin{array}{l}0.11 \\
0.06\end{array}$ & $\begin{array}{l}0.00 \\
0.01\end{array}$ & $\begin{array}{l}(\infty) \\
4.00\end{array}$ \\
\hline A. niger NRRL6I 5 & $\begin{array}{l}4 \\
7\end{array}$ & $\begin{array}{l}3.6 \\
5.6\end{array}$ & $\begin{array}{l}4 \cdot 25 \\
5 \cdot 62\end{array}$ & $\begin{array}{r}919 \\
\text { I I55 }\end{array}$ & $\begin{array}{l}0.09 \\
0.10\end{array}$ & $\begin{array}{l}0.01 \\
0.02\end{array}$ & $\begin{array}{l}6 \cdot 71 \\
5 \cdot 53\end{array}$ \\
\hline A. versicolor & $\begin{array}{l}4 \\
7\end{array}$ & $\begin{array}{l}3.5 \\
3 \cdot 0\end{array}$ & $\begin{array}{l}4 \cdot 75 \\
3 \cdot 62\end{array}$ & $\begin{array}{l}568 \\
598\end{array}$ & $\begin{array}{l}0.09 \\
0.14\end{array}$ & $\begin{array}{l}0.02 \\
0.00\end{array}$ & $\begin{array}{l}4.63 \\
(\infty)\end{array}$ \\
\hline Mucor hiemalis & $\begin{array}{l}4 \\
7\end{array}$ & $\begin{array}{l}5.6 \\
5.9\end{array}$ & $\begin{array}{l}6 \cdot 12 \\
4 \cdot 75\end{array}$ & $\begin{array}{l}204 \\
323\end{array}$ & $\begin{array}{l}0.02 \\
0.03\end{array}$ & $\begin{array}{l}0.00 \\
0.07\end{array}$ & $\begin{array}{l}(\infty) \\
0.39\end{array}$ \\
\hline Epicoccum purpurascens & $\begin{array}{l}4 \\
7\end{array}$ & $\begin{array}{l}3 \cdot 6 \\
6 \cdot 2\end{array}$ & $\begin{array}{l}6 \cdot 12 \\
7 \cdot 50\end{array}$ & $\begin{array}{l}957 \\
887\end{array}$ & $\begin{array}{l}0.01 \\
0.01\end{array}$ & $\begin{array}{l}0.04 \\
0.00\end{array}$ & $\begin{array}{l}0.22 \\
(\infty)\end{array}$ \\
\hline Penicillium expansum & $\begin{array}{l}4 \\
7\end{array}$ & $\begin{array}{l}3.4 \\
5.3\end{array}$ & $\begin{array}{l}7 \cdot 87 \\
4 \cdot 12\end{array}$ & $\begin{array}{l}\text { WG } \\
\text { WG }\end{array}$ & $\begin{array}{l}0.07 \\
0.19\end{array}$ & $\begin{array}{l}0.00 \\
0.00\end{array}$ & $\begin{array}{l}(\infty) \\
(\infty)\end{array}$ \\
\hline
\end{tabular}

wG, Weak growth.

* As $\Delta E_{280}$ of the trichloroacetic acid filtrate after incubation with casein.

† Calculated before 'rounding off'.

$\$$ No growth at 4 days.

Variations in the production of milk-clotting enzymes by Penicillium strains were also noted. Thus among the seven Penicillium strains tested, the culture filtrates of $P$. expansum, $P$. notatum 6I, $P$. chrysogenum and $P$. martensii clotted milk. Although the two last-named Penicillium strains produced the most active milk-clotting enzymes, the filtrates possessed high general proteolytic activity because of peptonization of the curds formed. The milkclotting action brought about by the culture filtrates of $P$. chrysogenum and $P$. martensii was therefore presumed to be due to general proteolytic action rather than to milk-clotting enzymes with limited proteolytic action. The same was also observed with culture filtrates of Cladosporium sp. 56 and Cunninghamella echinulata. The culture filtrates of other strains of these genera either possessed feeble milk-clotting activity, or none.

Curvularia lunata, Fusarium moniliforme and Pseudoarachniotus roseus produced mucilaginous materials coating the mycelia, but the culture filtrates possessed very weak milkclotting activities. This phenomenon was further investigated by growing these isolates for 
4 and 7 days (surface and shaken cultures) on a medium composed of $(\%, w / v)$ : corn-steep solids (2), asparagine (0.7), glucose (2) and peptone (I.5). Results were similar, and mycelial growth was good. Abdel-Fattah et al. $\left(\mathrm{I}_{972} b\right)$ reported that Penicillium citrinum produced active milk-clotting enzyme when cultured on a corn steep plus lactose medium. However, when the same isolate was cultured on skim milk solution, the culture filtrate possessed no milk-clotting activity and the mycelium was associated with mucilaginous material (AbdelFattah et al. $1972 b$ ). An inverse relationship may thus exist between the production of milk-clotting enzymes and the formation of mucilage by some fungi.

As shown in Table I, no relationship seemed to exist between the pH of a culture filtrate and its milk-clotting activity. Thus, though, in some isolates, culture filtrates of low $\mathrm{pH}$ (3.0) quickly clotted milk, others of the same $\mathrm{pH}$ showed no activity. The $\mathrm{pH}$ values of all the reaction mixtures (culture filtrate + milk) varied only within a limited range, from 6.0 to $6 \cdot 3$, probably because of the high buffering capacity of milk. The extent of milk-clotting activity was also independent of the total protein content of the culture filtrate.

To select a rennin-like milk-clotting enzyme, i.e. one with limited general proteolytic action, the tests on fungi were repeated with strains which showed milk-clotting activity without peptonization of curd (hence excluding Cladosporium sp. 56, $P$. chrysogenum, $P$. martensii and Cunninghamella echinulata). In this investigation each fungus was cultured for 4 and 7 days and the milk-clotting activity, proteolytic activity and the ratio between these activities were determined.

The data recorded in Table 2 indicate that the incubation time influenced the milk-clotting activity of the culture filtrate. With most of the fungal cultures investigated, this activity was related to mycelial growth, but not to $\mathrm{pH}$ changes of the culture filtrate during incubations. No consistent relationships were found between general proteolytic activity and the $\mathrm{pH}$, the protein content of the culture filtrate, or mycelial growth.

The ratio of milk-clotting activity to general proteolytic activity for an enzyme preparation is an index of its suitability as a rennin substitute. According to the results, Aspergillus fischeri, A. giganteus, A. niger 604 and, especially, Penicillium expansum appeared the most promising fungal isolates for production of rennin-like enzymes.

The results showed that milk-clotting and general proteolytic activities are different. Thus where association of the two enzymic activities occurred, their ratio varied not only from one isolate to another but also differed for the same fungal strain with the age of culture. These results are in agreement with those previously reported (Srinivasan et al. I964; Abdel-Fattah et al. 1972a).

The authors thank Professor H. M. Youssef, Botany Department, Faculty of Science, Alexandria University, Egypt, for his kind donation of the mucilage-producing fungal culture Pseudoarachniotus roseus and for his interest throughout the work.

\section{REFERENCES}

Abdel-Fattah, A. F., Mabrouk, S. S. \& El-Hawwary, N. M. (1972a). Distribution pattern of milkclotting and proteolytic activities in some fungi. Acta biologica Academiae scientiarum hungaricae 23, $55-60$.

Abdel-Fattah, A. F., Mabrouk, S. S. \& El-Hawwary, N. M. (1972 b). Production and some properties of rennin-like milk-clotting enzyme from Penicillium citrium. Journal of General Microbiology 70 I5I-I 55 .

ARIma, K., Iwasaki, S. \& TAMURA, G. (1967). Milk-clotting enzyme from microorganisms. I. Screening test and the identification of the potent fungus. Agricultural and Biological Chemistry 31, 540-545. 
BERGKVIst, R. (1963). The proteolytic enzymes of Aspergillus oryzae. I. Methods for the estimation and isolation of the proteolytic enzymes. Acta chemica scandinavica 17, 1521-1540.

BERRIDGE, N. J. (1952). Some observations on the determination of the activity of rennet. Analyst 77, 57-62. DAVIs, J. G. (1970). Rennet in the United Kingdom: past, present and future - a review. Industria latte 6, $179-197$.

Lowry, O. H., Rosebrough, N. J., FarR, A. L. \& Randall, R. J. (I95I). Protein measurements with the Folin phenol reagent. Journal of Biological Chemistry 193, 265-275.

Paleva, N. S. (1969). Rennin production by Aspergillus. Mikrobiologiya 38, 1002-1005.

Srinivasan, R. A., Iyengar, M. K. K., Babbar, I. J., Chakravorty, S. C., Dudani, A. T. \& Iya, K. K. (1964). Milk-clotting enzymes from micro-organisms. Applied Microbiology 12, 475-478.

VerINGA, H. A. (1961). Rennet substitutes - a review. Dairy Science Abstracts 23, 197-200.

Veselov, I. Y., Tipograph, D. Y. \& Petina, T. A. (1965). Aspergillus candidus as a producer of rennin. Prikladnaya biokhimija mikrobiologiya 1, 52-56. 